\title{
MILK Symposium review: Sustainability of dairy production and consumption in low-income countries with emphasis on productivity and environmental impact*
}

\author{
J. M. Tricarico, ${ }^{1} \dagger \odot$ E. Kebreab, ${ }^{2} \odot$ and M. A. Wattiaux ${ }^{3} \oplus$ \\ ${ }^{1}$ Innovation Center for US Dairy, Rosemont, IL 60018 \\ ${ }^{2}$ Department of Animal Science, University of California, Davis 95616 \\ ${ }^{3}$ Department of Dairy Science, University of Wisconsin, Madison 53706
}

\begin{abstract}
Sustainable milk production and consumption in low-income countries must address food security and climate change mitigation simultaneously. Socioeconomic sustainability is paramount in low-income countries, where milk production and consumption represent a vehicle to improve human nutrition and health, as well as the potential for economic opportunity and improved livelihood of subsistence farmers. These benefits can only be achieved with judicious use of animal stocks and agricultural practices that do not exhaust available natural resources, which are often shared by regional farming communities. Milk and dairy foods provide variety to the diet and make significant contributions to meeting the needs for high-quality protein, calcium, magnesium, selenium, riboflavin, vitamin $\mathrm{B}_{12}$, and pantothenic acid (vitamin $\mathrm{B}_{5}$ ) in at-risk populations, particularly children, pregnant women, and the elderly. Milk production in low-income countries occurs largely in smallholder mixed crop-livestock systems where animals play multiple roles and may suffer from undernutrition, leading to negligible or no milk production during several months of the year. Non-food roles of livestock include draft, fuel (manure), store of capital, and insurance against crop failure. These roles and the social standing associated with animal ownership may incentivize the maintenance of large herds that place stress on feed (land) and water resources. Under these circumstances, sustainable intensification (i.e., increasing milk production from currently available resources) represents the single most important and practical strategy to improve the sustainability of
\end{abstract}

Received January 27, 2020.

Accepted April 9, 2020.

*Presented at the MILK Symposium: Improving Milk Production, Quality, and Safety in Developing Countries at the ADSA Annual Meeting, Cincinnati, Ohio, June 2019.

†Corresponding author: Juan.Tricarico@dairy.org milk production and consumption in low-income countries. Improving the genetic potential of animals and the availability of quality feed, and providing balanced nutrition are the most promising strategies to improve milk production and sustainability in low-income countries. For example, the deficit for milk in Ethiopia is estimated at 4.5 billion liters/year, which can be closed, in part, with balanced animal nutrition. Milk production in low-income countries will be more sustainable if it relies on natural resources available locally and regionally to supply essential nutrients to at-risk human populations.

Key words: sustainability, dairy, low-income country

\section{INTRODUCTION}

The principles of sustainability apply to milk production, regardless of where a dairy farmer produces milk in the world. Sustainable production and consumption is defined by the European Federation of Chemical Engineering (2018) as production and use of products and services in a manner that is socially beneficial, economically viable, and environmentally benign over their whole life cycle. In addition, the United Nations Sustainable Development Goal 12 (UN DESA, 2018) states that sustainable consumption and production promote resource and energy efficiency and sustainable infrastructure, and provide access to basic services, green and decent jobs, and a better quality of life for all. Its implementation helps to increase productivity; achieve overall development plans; reduce future economic, environmental, and social costs; strengthen economic competitiveness; and reduce poverty. According to these definitions, the 3 pillars of sustainability - economic, social, and environmental - need to be considered and balanced for sustainable milk production and consumption in high-, mid- and low-income countries.

Although the same general principles of sustainability apply to milk production all over the world, attention is placed on distinct economic, social, and environmental 
issues in high-, mid-, and low-income countries. For example, animal welfare and environmental impacts on air and water are increasingly critical in high-income countries, whereas many low-income countries face high rates of childhood undernutrition and stunting, with long-term negative implications on health and socioeconomic development. Some of these low-income countries also have substantial livestock resources that, if sustainably intensified, could promote milk production and consumption to improve the nutrition, health, incomes, and livelihoods of the poor. The Innovation Lab for Livestock Systems (http://livestocklab.ifas.ufl.edu/ ), as part of the US government's global food security and hunger initiative "Feed the Future," identified 8 focal countries (Nepal, Cambodia, Ethiopia, Kenya, Uganda, Rwanda, Burkina Faso, and Niger) where low production, adulteration, and poor quality and safety of milk are major constraints to its consumption. The MILK Symposium, titled "Improving milk production, quality, safety and consumption in developing countries," was held during the 2019 American Dairy Science Association ${ }^{\circledR}$ annual meeting in Cincinnati, Ohio. This symposium highlighted the importance of milk for preventing stunting and characterized the risk, health, and economic impacts of food-borne pathogens and aflatoxins in milk. It also described successful interventions used in selected developing (hereafter "low-income") countries-Burkina Faso, Cambodia, Ethiopia, Kenya, Nepal, Niger, Rwanda, and Uganda - to improve sustainable intensification of milk production and increase milk consumption in at-risk populations (e.g., children under 5 yr of age, pregnant women, and the elderly). This review discusses factors related to the sustainability of milk production in low-income countries that were presented at the 2019 MILK Symposium. The emphasis was placed on productivity, environmental impact, and interventions that can support sustainable intensification of milk production to address food security in lowincome countries. Important government policies (e.g., international trade and subsidies) and institutional factors (e.g., milk marketing organizations across the value chain) necessary to support sustainable intensification, including handling and marketing of milk after the farm gate, are outside the scope of this review and therefore not discussed. A brief description of socioeconomic considerations for sustainable milk production is followed by discussions of environmental impact and sustainable intensification. In the last section, on-farm interventions on animal nutrition, management, and breeding are discussed, with an emphasis on animal nutrition, including the presentation of a case study on the development of ration formulation software for Ethiopia.

\section{SOCIAL AND ECONOMIC CONSIDERATIONS OF MILK PRODUCTION AND CONSUMPTION IN LOW-INCOME COUNTRIES}

The discussion of sustainability is not limited to environmental concerns, but also incorporates social and economic considerations. A comprehensive approach to sustainability is extremely important in low-income countries experiencing high rates of undernutrition, including micronutrient deficiencies that lead to child stunting and wasting. Sustainability under these conditions requires that emphasis be placed not only on the supply of nutrients to populations under risk but also on education about the contributions of milk and dairy foods on human growth, development, and health in general. Undernutrition refers to inadequate intake of energy or protein and vitamin and mineral deficiencies (WHO, 2018). The broader term "malnutrition" includes all forms of undernutrition, in addition to overweight, obesity, and resulting diet-related noncommunicable diseases (WHO, 2018). Malnutrition, including undernutrition, affects not only the health of individuals, it is also expensive for society as a whole. The effects of chronic undernutrition include poor school performance and reduced economic productivity (HLPE, 2017). Malnutrition also reduces human productivity and creates costs for the health care system. The annual economic cost of undernutrition ranges from 2 to $3 \%$ of gross domestic product (GDP) in some countries and is as high as $11 \%$ of GDP in some countries in Africa and Asia (World Bank, 2019). Protein undernutrition as well as several micronutrient deficiencies are significant concerns in low-income countries (Bailey et al., 2015). Increased milk production and consumption has the potential to improve the supply of nutrients and the nutritional status of vulnerable populations.

Milk and dairy foods provide a high-quality nutrient package that can be difficult to meet without animalsourced foods in the diet (Fulgoni et al., 2011). For example, in the United States, where a wide variety of food options are readily available, milk is the leading source of several essential nutrients including protein, calcium, phosphorus, magnesium, potassium, vitamin A, vitamin $\mathrm{B}_{12}$, and riboflavin for children from 2 to 18 yr of age (Keast et al., 2013). Strong evidence indicates that animal-sourced foods and the nutrients they supply provide beneficial health outcomes; for example, reduced stunting (Headey et al., 2018) and improved cognitive function in children (FAO, 2011a; Balehegn et al., 2019). Even in small amounts, high-quality protein and highly bioavailable micronutrients can play an important role in the nutritional status of low-income households by addressing micro- and macronutrient 
deficiencies, particularly in vulnerable populations, such as children, adolescent females, and pregnant and lactating women. Meat, for example, provides easily absorbable heme iron and can help in the absorption of iron from plant foods (Bender 1992), helping to prevent iron deficiency, which is a preventable cause of anemia. Meat and milk are good sources of vitamin $\mathrm{B}_{12}$, riboflavin, and vitamin A. Meat also provides zinc, and milk is a rich source of calcium. In parts of South Asia, Africa, and the Middle East, dairy milk is particularly important in the diet as well as in supporting local industry (FAO, 2011a).

Dairying offers the potential for a positive effect on poverty reduction and socioeconomic development. A systematic literature assessment conducted by the Food and Agriculture Organization of the United Nations (FAO), Global Dairy Platform, and International Farm Comparison Network (IFCN) evaluated the potential for future expansion of dairy products in low-income countries as a tool to improve human welfare (FAO, GDP, and IFCN, 2018). The authors reviewed several ways in which cow ownership can affect socioeconomic welfare. These included enhanced consumption of milk, increased crop production using manure, increased income from sales, and subsequent investment of revenues in areas that add to local economic growth. Published studies demonstrated consistent increases in household milk consumption and diet quality with important implications for improved nutritional outcomes (Hoddinott et al., 2015; FAO, GDP, and IFCN, 2018). A statistically significant increase in household income ranging from 27 to $115 \%$ was also attributed, in 6 studies, to dairy cow ownership in Bangladesh, Ethiopia, Kenya, India, and Tanzania (FAO, GDP, and IFCN, 2018). These studies support the notion that livestock ownership and dairying in low-income countries may significantly improve nutrition as well as economic outcomes.

Most dairy animals in low-income countries are kept by the rural poor. These animals serve many economic and social functions that in high- and mid-income countries are supplied by infrastructure associated with socioeconomic development and increased GDP (Herrero et al., 2013). These animals represent a source of income, livelihood diversification, savings and insurance, draft power and transportation, fertilizer or construction material (manure), and housing (hides), and allow households to benefit from common-property resources such as communal grazing land. In addition, the animals play important roles in ceremonies or are used for dowry, making them essential for some societies to fulfill their social or religious obligations. These socioeconomic functions are supported by larger herd sizes regardless of animal productivity and are in conflict with reducing the populations of unproductive animals and their associated environmental pressures. Nevertheless, decreasing the number of animals raised while increasing the productivity of individual animals may be beneficial to animal (and human) nutrition and health as well as to environmental outcomes. Therefore, there is a need to consider the alignment between the socioeconomic functions that dairy cattle play in many low-income countries and their associated environmental impacts. The incentives for herd sizes to grow in low-income countries will not disappear until socially and economically acceptable innovations supplement or replace the multiple roles and services that these dairy animals currently provide to their owners.

\section{ENVIRONMENTAL IMPACT OF MILK PRODUCTION AND CONSUMPTION IN LOW-INCOME COUNTRIES}

The dairy sector is growing rapidly, particularly in low-income countries (Wattiaux, 2017). Animal source foods, including milk and dairy foods, are desirable and their consumption increases with increasing populations and household incomes (FAO, 2020). There is a strong focus on quantifying the environmental impact of milk production and consumption across the globe. Yet, because detailed activity data are lacking, there are no accurate estimates of natural resources use and environmental impact by dairy animals in low-income countries, except for those that rely on the total number of animals and rudimentary estimates of impact factors (IPCC, 2006; Wattiaux, 2017). For this reason, greenhouse gas (GHG) emissions are the most common environmental impact reported for low-income countries. Global GHG emissions from milk production, processing, and transportation represent $2.7 \%$ of global anthropogenic GHG emissions, where global emissions per unit of milk (i.e., emission intensity) are reported at $2.4 \mathrm{~kg}$ of $\mathrm{CO}_{2}$-equivalents $\left(\mathbf{C O}_{2}\right.$-eq $)$ per $\mathrm{kg}$ of fat- and protein-corrected milk (FPCM; Gerber et al., 2010).

The pressure on natural resources increases in low-income countries because most rely primarily on increasing the number of dairy animals to meet the growing demand for milk and dairy foods. Figure 1 illustrates how milk supply, number of lactating cows, milk yield per cow, and enteric methane emissions intensity changed, on average, over the last 5 decades relative to their corresponding averages between 1961 and 1967 in 3 focal countries for the "Feed the Future Innovation Lab for Livestock Systems" compared with that in the United States (FAO, 2018). For example, milk production increased by $738 \%$ in Uganda, driven exclusively by growth in the population of lactating 
cows, without a change in milk yield per cow over the entire 50-yr period. Milk production in Nepal increased $302 \%$ from a combination of growth in lactating cow population and milk yield improvements. Milk yield improvements drove milk production growth in Ethiopia between 1997 and 2007, whereas a large increase in lactating cow numbers was the primary driver during the last decade, even as cow productivity decreased. The United States exemplifies the trajectory followed by many high-income countries, where milk production increased $(163 \%)$ as a result of milk yield improvements (271\%) while the population of lactating cows decreased $(60 \%)$ considerably. In all cases illustrated in Figure 1 , enteric methane emissions intensity ( $\mathrm{kg}$ of $\mathrm{CO}_{2}$-eq/ $\mathrm{kg}$ of milk) decreased as milk yield per cow increased. The opportunity to increase milk supply to meet growing demand and simultaneously reduce environmental impact through milk yield improvement is particularly attractive in low-income countries because most individual cows produce very low quantities of milk.

In many low-income countries, natural resources, such as water and feedstock, may not be purposefully managed. For instance, natural pastures may be overgrazed or water resources offered to many more animals than they can support. Under these conditions, each animal only has access to suboptimal resources. When too many animals compete for a limited resource, growth, health, milk and meat production, and reproduction may be jeopardized. This situation greatly reduces the efficiency by which natural resources are converted into milk by dairy animals. As described above, the main confounding issue is that animals provide non-food social and economic services that are better served by the ownership of more animals rather than by their ability to efficiently convert natural resources into food.

\section{SUSTAINABLE INTENSIFICATION OF MILK PRODUCTION AND CONSUMPTION IN LOW-INCOME COUNTRIES}

The global livestock sector contributes $14.5 \%$ of anthropogenic GHG emissions, accounting for both direct and indirect emissions, including land use change, with $20 \%$ of the total coming from the dairy sector and $41 \%$ from the beef sector (Gerber et al., 2013). The authors estimate that feed production, enteric methane emissions, and manure storage contribute to 45,39 , and $10 \%$ of emissions, respectively. Emissions of GHG are

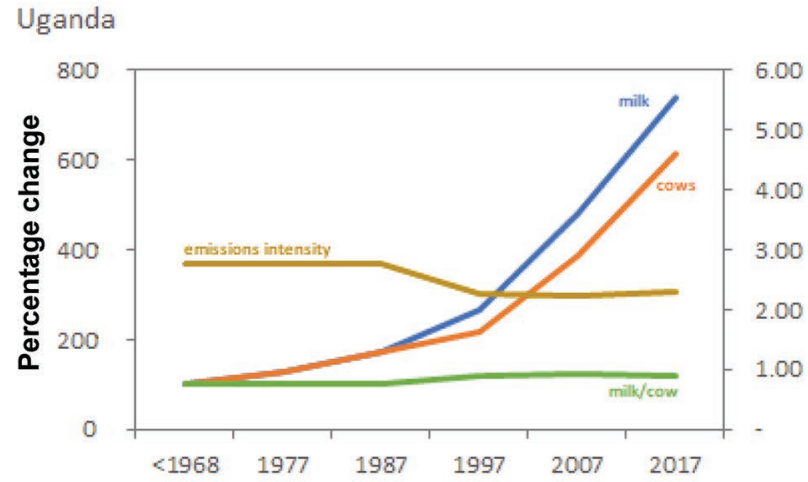

Ethiopia

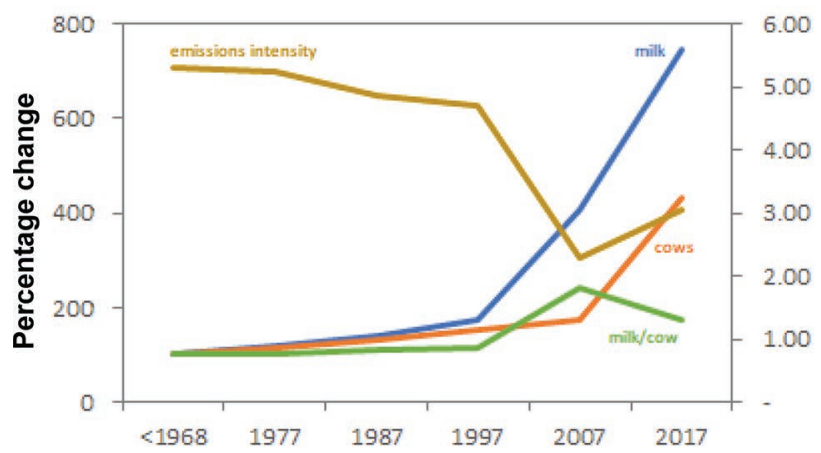

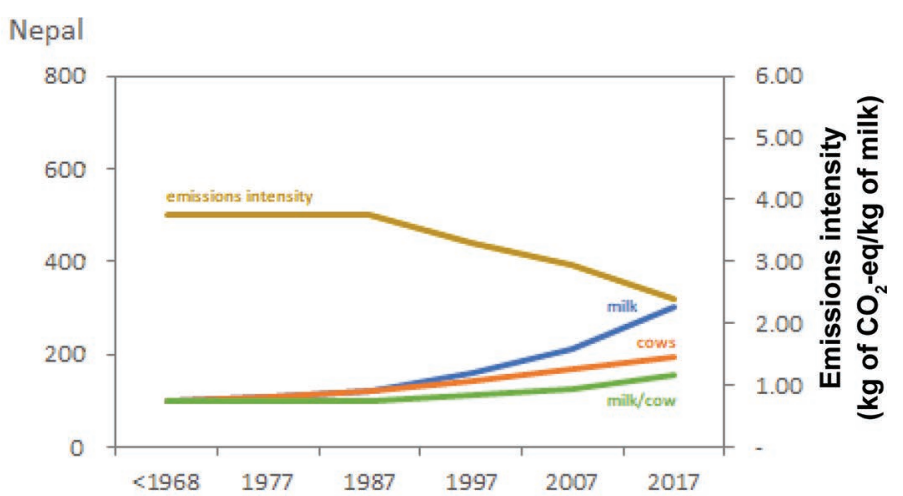

United States

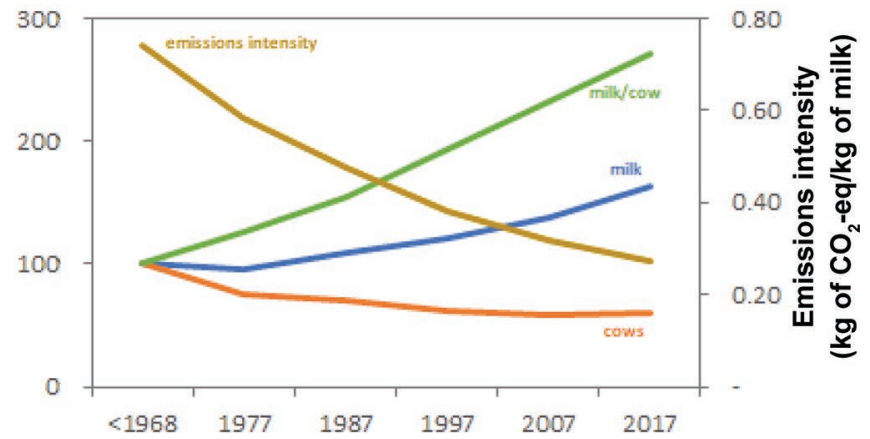

Figure 1. Percentage change (relative to 1961-1967 baseline) in annual milk production, population of lactating cows, milk yield per cow (primary y-axis on left), and average enteric methane emissions intensity ( $\mathrm{kg}$ of $\mathrm{CO}_{2}$-equivalents $/ \mathrm{kg}$ of milk; secondary y-axis on right) for the last 5 decades ending in 2017 in Uganda, Nepal, and Ethiopia compared with the United States (FAO, 2018). 
reported in absolute terms $(\mathrm{g} / \mathrm{d})$, yield ( $\mathrm{g} / \mathrm{kg}$ of DMI), or intensity $(\mathrm{g} / \mathrm{kg}$ of animal product, usually corrected for nutrient concentration). Emissions intensity (in $\mathrm{kg}$ of $\mathrm{CO}_{2}-\mathrm{eq} / \mathrm{kg}$ of $\mathrm{FPCM}$ ) is the fundamental metric for sustainable intensification of milk production because it considers both environmental impact and food production and provides a direct link to the use efficiency of natural resources. For example, Gerber et al. (2013) showed a strong relationship in dairy between productivity and emissions intensity across countries. Emissions intensity decreases as yield increases up to a relatively high level of annual productivity of approximately $6,000 \mathrm{~kg}$ of $\mathrm{FPCM} / \mathrm{cow}$. The GHG intensity in low-income countries varies widely. Hagemann et al. (2012) estimated that the difference between minimum and maximum emissions intensity to be $260 \%$ in Africa and $160 \%$ in Asia. The authors reported that the greatest emission rates were found in Cameroon at $4.08 \mathrm{~kg}$ of $\mathrm{CO}_{2}-\mathrm{eq} / \mathrm{kg}$ of FPCM, followed by Bangladesh with $3.69 \mathrm{~kg}$ of $\mathrm{CO}_{2}-\mathrm{eq} / \mathrm{kg}$ of FPCM. One of the factors contributing to greater GHG intensity in low-income countries is the use of dual-purpose breeds that tend to have lower milk yields and greater maintenance requirements associated with non-food production purposes, such as draft power. Interestingly, Norway had the greatest GHG intensity compared with other European high-income countries because their farms usually raise dual-purpose breeds (Hagemann et al., 2012).

There is strong evidence that on-farm productivity and GHG emissions intensity are inversely related. Gerber et al. (2013) provide 3 main reasons for the lower GHG emission intensities associated with greater milk-producing animals. First is the dilution of maintenance effect, whereby GHG emissions are spread over more units of milk and less over the maintenance requirements as milk yield increases. Second is the use of farming practices and technologies, such as highquality feed and specialized animal genetics, that often increase milk production and reduce emissions simultaneously. Finally, herd management, animal health, and husbandry practices that result in a greater proportion of total resources destined for productive purposes at the herd level reduce the need for more lactating and replacement animals to produce the amount of milk necessary to meet market demands. Therefore, given the prevailing conditions of many low-income countries, increasing productivity at the animal and herd levels is likely to reduce GHG emissions intensity while simultaneously increasing milk supply.

Mitigation of emissions generally focuses on major sources such as feed production and enteric methane production. For example, Caro et al. (2016) evaluated the global potential reduction of enteric methane emissions released from dairy cattle through amendment of traditional diets in 183 countries aggregated to 11 regions. When amending diets by increasing lipid and decreasing fiber concentrations, the authors estimated a global potential reduction of $15.7 \%$ of enteric methane emissions from dairy cattle, with a concomitant increase in global milk production of $13 \%$. They reported that the greatest potential reduction of methane intensity occurred in Africa followed by South America and Asia $(55,46$, and $34 \%$, respectively). However, nitrous oxide emissions were likely to increase by $21 \%$ due to diet amendment but a decrease in methane emissions from manure management was predicted. Similarly, Pressman et al. (2018) evaluated the GHG mitigation potential of improving the feed quality of crop residues such as corn and wheat stover, and teff (a lovegrass species: Eragrostis tef) and barley straw in East Africa. The authors reported that although there was an increase in nitrous oxide emissions, the net GHG reduction in emission intensity was $0.63 \mathrm{~kg}$ of $\mathrm{CO}_{2}$-eq $/ \mathrm{kg}$ of milk per year (27.6\% decrease) in Kenya and $0.82 \mathrm{~kg}$ of $\mathrm{CO}_{2^{-}}$ eq $/ \mathrm{kg}$ of milk per year $(31.3 \%$ decrease) in Ethiopia. They also observed an increase in milk production of about $33 \%$. The above studies agree that, in general, an increase in productivity of dairy cattle might be an effective way of reducing GHG emission intensity in low-income countries.

Sustainable intensification represents the greatest opportunity for low-income countries to increase the supply of human-edible nutrients to vulnerable populations while reducing pressures on natural resources and environmental impact. According to Garnett et al. (2013), sustainable intensification in agriculture is defined as increasing food production from existing farmland in ways that reduce environmental pressure and do not undermine future capacity to produce food. Under this framework, sustainable intensification of milk production would rest on the premise of increasing milk production, primarily through increased milk yields without conversion of additional nonagricultural land, with major reductions in environmental impact in context- and location-specific manner and considering the merits of diverse technologies and practices.

The chances for acceptance and adoption of sustainable intensification of milk production in many lowincome countries are likely to increase as the other roles and socioeconomic services that dairy animals provide are supplied by different means. Specialized farmers need to consider dairy cows primarily as a resource to transform feed and water into human-edible food rather than as an economic asset or an insurance policy. Sustainable intensification is positioned as one of the most important means to increase food security while reducing environmental impact. Yet optimal milk production levels per cow for individual low-income countries 
remain an open question. According to FAO (2011a), "rather than attempting to bring all to the highest level of productivity, a sustainable goal for mixed farming in particular might call for bringing lower performers up towards the middle." Therefore, current efforts in many low-income countries are based on interventions that increase animal productivity, relying on technologies available in high-income countries. Low-income countries have different resources and climatic and geographic conditions than high-income countries, so most interventions cannot be adopted directly. Instead, successful intensification in low-income countries will likely result from defining regional production goals and adapting knowledge and practices to the local conditions.

\section{INTERVENTIONS FOR SUSTAINABLE MILK PRODUCTION IN LOW-INCOME COUNTRIES}

The adoption of technology was vital for historical productivity improvements in the US dairy sector (Weimar and Blayney, 1994). However, technological advancement is not enough; it must be accompanied by economic and social innovation to drive sustainable intensification and effectively address the rising demand for milk and dairy foods in low-income countries. These technological, economic, and social innovations will need to be context- and location-specific because various countries, regions, and even smallholder farmers within them will not follow the same development trajectory. Although preservation of soil, air, water, and natural ecosystem integrity are important issues when discussing sustainability, they are only a part of larger challenges and may not be the most immediate concerns of dairy farmers in low-income countries. Other issues are associated with the milk production process itself. Farmers are challenged to produce safe and high-quality milk from healthy animals, which imposes demands on management of animal health, milking hygiene, animal welfare, and feed and water (FAO-IDF, 2011). Many practices and technologies exist today for consideration by farmers in low-income countries. However, technology adoption is a complex issue that depends on many factors, including the local infrastructure (e.g., electricity) and farm and household characteristics (e.g., level of formal education and training; Martínez-García et al., 2015). Some practices and technologies can be applied directly but most require adaptation to local conditions, which includes considering the type of farming system used by the smallholder wishing to adopt them. The interventions with the greatest probabilities for success in low-income countries that are relevant to various smallholder mixed crop-livestock systems are listed in 3 categories in Table 1.

\section{Animal Nutrition}

According to FAO (2011a), "one of the major constraints for intensification of small-scale livestock production is the lack of good quality feed resources." Dairy animals in low-income countries often suffer from malnutrition in several months throughout the year as a result of climatic, economic, and management conditions (Val-Arreola et al., 2004; Dizyee et al., 2019). Animal health and milk production cannot be sustained if dairy cows are underfed and undernourished. In most cases, simply increasing feed intake will have a positive impact on meeting nutrient requirements and preventing deficiencies that limit milk production. Often, the first challenge in many low-income countries is to secure feed throughout the year. Insufficient feed for the number and types (i.e., growing, periparturient, and lactating) of dairy animals held by farmers is common during the winter (temperate regions) or dry (tropical regions) season in low-income countries. Dairy animals will first cover maintenance nutrient requirements before using nutrients for productive purposes. Thus, when feed is limited, milk production, reproduction, growth, and eventually health may be compromised depending on the magnitude and period of the limitation (FAO, 2011b). Managing available feed resources and the number and type of dairy animals is critical to improve their overall nutritional status, their productivity, and the sustainability of milk production. The second challenge is to secure good quality feed. Forages are usually the major contributors to dairy cattle diets and supply several nutrients including energy, protein, and minerals. Forage quality depends on both composition and digestibility.

The first category of practices and technology in Table 1 addresses this issue by focusing on improving dairy cattle nutrition through feeds and feeding. To do this, it is essential to train farmers to better understand the nutrient requirements of their dairy animals and the nutrients supplied by the feed resources that are available to them (see case study below). For the most part, the 3 main strategies within this category are to increase feed intake of many animals. Nevertheless, raising fewer animals to provide enough feed and water for each lactating cow to produce larger quantities of milk (Tarawali et al., 2011) may require a paradigm shift for many smallholders. Feed management practices, such as offering more feed per animal and increased feeding frequency (Allen, 2000) or management-intensive grazing (DeRamus et al., 2003) can provide immediate benefits. Second is to increase the energy density of the diet; for example, feeding by-products and concentrates when forage supply is limited during the dry or winter seasons (FAO, 2011b). Third is to provide 
Table 1. Summary of interventions for consideration by farmers for sustainable intensification of milk production in low-income countries ${ }^{1}$

\begin{tabular}{|c|c|}
\hline Intervention & Action \\
\hline \multicolumn{2}{|c|}{ Improve dairy cattle nutrition through feeds and feeding } \\
\hline \multirow[t]{2}{*}{ Increase feed intake } & Offer more feed \\
\hline & Use management-intensive grazing (e.g., rotational grazing) \\
\hline \multirow{3}{*}{ Increase dietary energy and protein density } & Improve forage management and quality \\
\hline & Feed available concentrates (grains, oilseeds, by-products) \\
\hline & Process feeds (especially low-quality feeds) \\
\hline Prevent nutritional deficiencies & Provide strategic macro- and micro-supplementation \\
\hline \multicolumn{2}{|c|}{ Use good husbandry practices to raise healthy animals } \\
\hline \multirow[t]{4}{*}{ Raise healthy calves and heifers promptly } & Keep records on growth, health, and breeding \\
\hline & Feed colostrum, vaccinate, and reduce stress to prevent disease \\
\hline & Diagnose and treat disease \\
\hline & Breed at weight for target age at first calving \\
\hline Maintain healthy and productive cows & Cull unproductive and infertile animals \\
\hline \multicolumn{2}{|l|}{ Breed selectively to improve genetic potential } \\
\hline \multirow[t]{3}{*}{ Collect and share animal records } & $\begin{array}{l}\text { Collect individual animal data on milk yield, disease, and reproduction events } \\
\text { (using modern technology when available) }\end{array}$ \\
\hline & $\begin{array}{l}\text { Genotype animals for breed composition, parentage determination, and genomic } \\
\text { breeding values }\end{array}$ \\
\hline & Reduce inbreeding \\
\hline \multirow[t]{3}{*}{ Match genotypes to production environment } & Define selection objectives (milk yield, fertility, and disease resistance) \\
\hline & Use crossbreeding, AI, and genomic breeding values \\
\hline & $\begin{array}{l}\text { Use high-yield imported breeds strategically ( }<50 \% \text { for poor nutrition and } \\
\text { husbandry and }>50 \% \text { for good nutrition and husbandry) }\end{array}$ \\
\hline
\end{tabular}

${ }^{1}$ Summarized and adapted from FAO-IDF (2011), Innovation Center for US Dairy (2014), Losinger and Heinrichs (1996), Kiplagat et al. (2012), Ducrocq et al. (2018), and Marshall et al. (2019).

targeted supplementation of macro- and micronutrients to prevent vitamin and mineral deficiencies that limit growth, reproduction, and milk production, and that compromise animal health (FAO, 2011b). These strategies would help farmers in low-income countries better manage their herds and feed resources while increasing milk supply.

Farming systems in most low-income countries are generally quite different from those in temperate countries (Delgado et al., 1999) because of several factors, including climate, nutritional value of feed ingredients, and genetic potential of the animals. Despite these differences, the feeding recommendations of dairy cattle in low-income countries are still largely based on standards that were established in temperate regions, such as NRC (2001), which was mostly based on Holstein and Jersey cattle genotypes. Tropical dairy and multipurpose breeds tend to be smaller, with a slower growth rate and lower milk production compared with temperate breeds; however, they tend to be better adapted to hot and humid climates with poor quality feeds, and their nutritional requirements are likely to be different (Paul et al., 2004). Salah et al. (2014) conducted a meta-analysis of digestion studies performed in tropical countries that included a large diversity of feed rations and animal genotypes. The authors concluded that there was a greater energy requirement for tropical ruminants than those proposed in the international feed system standards.

Knowledge of nutritional requirements of dairy cattle will help in formulating rations that optimize resource use efficiency. To achieve improvements in animal production under smallholder mixed crop-livestock farming systems, careful attention must be given to the way feed ingredients are formulated to provide the appropriate levels of energy, protein, minerals, and vitamins. In several Asian and African countries, the use of animals with higher genetic potential is promoted to improve animal productivity. However, without proper nutrition, the potential for higher production cannot be met and imported genetics are underutilized (Marshall et al., 2019). Nutrient deficiencies lead to increased disease occurrence and reproductive problems. Therefore, information on nutrient concentrations of feed resources and the genetic potential of animals is important in formulating appropriate diets. 


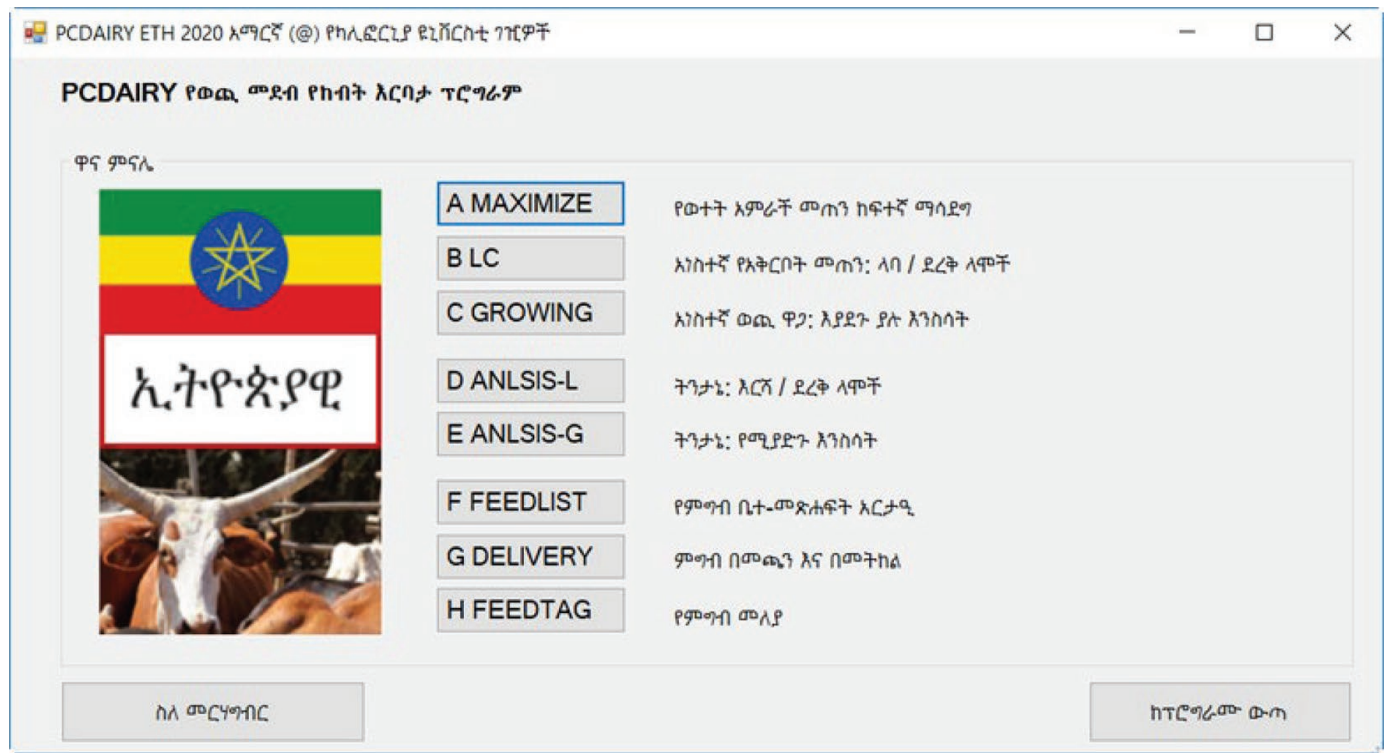

Figure 2. Interface of PCDAIRY (University of California, Davis) in Amharic for use in Ethiopia. PCDAIRY is a ration formulation software to optimize feed resources using a linear programming technique.

One of the contributors to improved productivity in the developed world has been the use of linear programming techniques to formulate rations in which various feed ingredients are combined to provide the required nutrients to animals. The formulated ration is then expected to supply all essential nutrients and energy to maintain vital physiological functions of growth, reproduction, and health of animals at different stages of production. As the availability and cost of feed changes, it is then possible to formulate rations using software to reduce cost, maximize productivity, and deliver the necessary nutrients using constraints to limit any undesirable traits of ingredients such as level of antinutritional factors.

\section{Case Study: Development of Ration Formulation Software for Ethiopia}

According to FAO (2012), balanced ration formulation in India increased daily income from rearing livestock by about $10 \%$. Similarly, using currently available feed resources, Blümmel et al. (2009) estimated that milk yield per animal in India could be increased from the national average of 3.6 to $9 \mathrm{~L} / \mathrm{d}$ by using better-formulated diets. Ration formulation software is an important tool for economic sustainability of smallholder dairy farms. For example, Goswami et al. (2013) demonstrated the feasibility of reducing feed cost by $19 \%$ compared with standard practice when formulating diets for crossbred dairy cows yielding 5 to $10 \mathrm{~kg}$ of milk/d in central India. Here, we describe a case study on the development of a ration formulation software in the Amharic language for use in Ethiopia.

The software PCDAIRY (University of California, Davis) is a modification of a package of computer programs for formulating and analyzing rations for dairy cattle. PCDAIRY runs on all Windows operating system versions back to Windows 95 . The program allows formulation and evaluation of rations for various classes of dairy cattle, as well as creation of user-selected summarization printouts. One of the important features of any ration formulation software is its feed library. It is crucial that the feed library contains nutrient analysis of the variety of feed available in the area in which it is intended to be used. The Ethiopian software, for example, contains 250 feeds, and a similar software for Vietnam contains 992 local feeds (Figure 2).

\section{Animal Management}

The second category of practices and technology focuses on properly managing the dairy animals to reduce stress and provide conditions conducive to improved health, growth, reproduction, and milk production (Table 1). Raising healthy animals promptly is important. Milk is only produced by cows that have birthed a calf. So, young animals need to remain healthy and grow at an appropriate rate for them to go through puberty, pregnancy, and calving at a reasonable weight and age. Many practices that target health status and growth of young dairy calves and heifers can be adapted to low-income country conditions. These practices include 
keeping records on health events, growth, and breeding; feeding colostrum to newborn calves; vaccinating animals, reducing environmental stress; diagnosing and treating disease; and breeding animals at the appropriate weight (FAO-IDF, 2011).

Consuming appropriate amounts of water by all dairy animals and especially by lactating cows is of paramount importance because milk is $88 \%$ water by weight. Water is a critical nutrient that needs to be considered separately from feed. Providing enough clean and highquality drinking water is critical (FAO-IDF, 2011). The challenge is that in many low-income countries water may be severely limited, even for human consumption. Under these conditions, emphasis needs to be placed on basic infrastructure to make water available even before farmers are educated on specific management practices that increase water consumption by dairy animals.

Maintaining healthy and productive lactating cows while actively culling unproductive and infertile cows is also important. The sale of unproductive and infertile animals contributes to the beef supply chain and provides farmers an alternative source of income. This concept is directly linked to production efficiency, natural resource use, and sustainable intensification. There are many practices and tools to maintain healthy and productive lactating cows, such as detecting estrus and diagnosing pregnancy to identify animals that need to be handled and managed differently to meet their specific needs (IAEA, 2007). For example, pre- and postpartum dairy cows require special handling and nutrition to reduce stress before, during, and immediately after parturition. Additional recommended practices include the diagnosis and treatment of postpartum diseases and mastitis.

\section{Animal Breeding and Genetics}

The third and final category of practices and technology in Table 1 is selective breeding to improve the genetic potential for milk production and adaptability of the dairy animals. Native animals are usually well adapted to the climate and sources of stress in lowincome countries such as heat and endemic diseases. However, these animals were not selectively bred for greater milk production. Thus, they are not the animals that have the genetic ability to produce more milk when feeding and management are improved. The overall goals of a successful selective breeding program in lowincome countries are to increase milk production and reproductive performance potentials while maintaining fitness traits responsible for adaptation to the diverse and predominantly tropical environments characterized by harsh and extreme climatic conditions, seasonal feed and water scarcity, heat stress, high solar radiation, widespread pathogens, parasitic infections, and disease epidemics (Marshall et al., 2019).

There are 2 important considerations when breeding dairy animals selectively in low-income countries. The first is to collect and share animal records. This is a basic condition and the practice that allowed farmers in high-income countries to dramatically increase milk production over the years (Losinger and Heinrichs, 1996). Collecting individual animal data on milk production and disease and reproduction events is basic information necessary for farmers to make better management decisions. Identifying the relevant traits to record and low-income inexpensive and easy-to-use devices for phenotyping is particularly important to enable selective breeding by farmers in low-income countries ( Ducrocq et al., 2018). Education on animal husbandry and breeding practices are critical aspects of any genetic improvement program. Increasing literacy and training among farmers in low-income countries will be required to achieve this goal. In some instances, new technologies can be introduced more rapidly, efficiently accelerating the innovation trajectory in low-income countries. For example, genotyping dairy animals to understand breed composition, determine parentage, and obtain breeding values is possible now in low-income countries to improve the genetic potential for desirable characteristics such as milk production and resistance to disease and reduce inbreeding and its deleterious effects (Ducrocq et al., 2018; Mrode et al., 2018).

Generally, the practices to implement genetic programs for greater milk production per cow in low-income countries include breed substitution, crossbreeding, and native breed improvement (Marshall et al., 2019). Although the latter may have certain sustainability advantages (e.g., based on local resources) it would be the most difficult to implement and would bring about results more slowly than the alternatives. In addition to starting with low-milk-producing animals, native breed improvement programs require a complex infrastructure to record pedigree, to phenotype the population of cows, and to estimate breeding values, all of which are expensive to establish and rarely available in low-income countries. Breed substitution may be done with more productive native breeds or adapted breeds originating from other tropical countries. In crossbreeding, usually a highly adapted but low-producing native breed is crossed with a poorly adapted but high-producing imported breed from temperate regions. Finally, when making decisions on which animals to cull and which to breed, matching the genotypes to the production environment is critical. Therefore, farmers in low-income countries should consider the relative strengths and weaknesses and feasibility of successfully using crossbreeding, AI, and genomic breeding values, especially in 
the light of predefined selection objectives that match their conditions (Kiplagat et al., 2012). This might include selecting for milk yield and improved fertility in general, but also for resistance to specific endemic diseases of importance to each location. Introducing genes for high milk production may be beneficial for farmers in low-income countries. According to Kavoi et al. (2010), imported dairy breeds (Friesian, Ayrshire, Guernsey, and Jersey) adapted to the conditions of the drier transitional zones (i.e., higher altitudes with more temperate climates) of Kenya were economically more efficient for surveyed smallholder dairy farms than the native breeds (Sahiwal, Boran, Zebu, and Zebu cross). The level of foreign genes introduced into a native population through crossbreeding should be considered, depending on specific local conditions. For example, farmers in low-income countries will be better served by incorporating less than $50 \%$ high-yielding imported breeds when animal nutrition and husbandry practices are poor but using more than $50 \%$ when good nutrition and animal husbandry practices can be provided to the dairy animals to take advantage of their ability to produce more milk (Marshall et al., 2019).

\section{CONCLUSIONS}

Sustainable milk production in low-income countries is a balancing act between responsible natural resource use and various socioeconomic services that dairy animals provide to the often-poor community members that raise them. Food security and proper nutrition are paramount to reduce and eventually eliminate malnutrition in vulnerable populations and particularly childhood wasting and stunting. Failing to address these issues has both short- and long-term negative implications on human health, welfare of households, and shared economic prosperity in the socioeconomic development of low-income countries. Milk and dairy foods supply high-quality nutrients that provide health benefits to vulnerable and often marginalized populations. These benefits would be difficult to achieve without these foods in the diet. Increasing milk supply and consumption (i.e., demand) in low-income countries can improve human nutrition and health, increase incomes, and improve the livelihoods of farmers and their families. Lowincome countries face many challenges to sustainably grow and develop their dairy industries to address food security and climate change mitigation simultaneously. In some regions of low-income countries where livestock have an important cultural relevance, there are incentives to maintain large herds of unproductive animals. Amount and quality of feed in these traditional mixed livestock-crop systems are often inadequate, leading to animal malnutrition during several months of the year.
Additional challenges on the production side include unfavorable climate and natural resources (e.g., soil fertility and water resources), high disease pressure, lack of infrastructure, and limited market access. There are also many challenges to the removal of barriers to milk and dairy food consumption in spite of their nutritional and health benefits. Thus, in many low-income countries, sustainable intensification increasing milk production from currently available resources is a critical strategy. Simultaneously, increasing milk consumption in vulnerable populations will require concerted multidisciplinary and multisectoral initiatives involving both the public and private sectors. Low-income countries need to define production and consumption objectives that align with their natural resources and social conditions to formulate intensification plans that promote growth and development of their dairy industry that balance the 3 pillars of sustainability. Although many critical practices and technologies currently used in high- and mid-income countries can be adapted to low-income country conditions, long-term sustainable intensification of dairy production and consumption in low-income countries will depend on increased public investment in locally relevant research and extension programs, basic infrastructure, and the strengthening of regulatory and policy frameworks.

\section{ACKNOWLEDGMENTS}

E. Kebreab received funding from the United States Agency for International Development (USAID) Bureau for Food Security under Agreement \# AID-OAAL-15-00003 as part of Feed the Future Innovation Lab for Livestock Systems. Additional funding was received from Bill \& Melinda Gates Foundation (Seattle, WA). Any opinions, findings, conclusions, or recommendations expressed here are those of the authors alone. The authors have not stated any conflicts of interest.

\section{REFERENCES}

Allen, M. S. 2000. Effects of diet on short-term regulation of feed intake by lactating dairy cattle. J. Dairy Sci. 83:1598-1624. https:// doi.org/10.3168/jds.S0022-0302(00)75030-2.

Bailey, R. L., K. P. West Jr., and R. E. Black. 2015. The epidemiology of global micronutrient deficiencies. Ann. Nutr. Metab. 66(Suppl. 2):22-33. https://doi.org/10.1159/000371618.

Balehegn, M., Z. Mekuriaw, L. Miller, S. McKune, and A. Adesogan. 2019. Animal-sourced foods for improved cognitive development. Anim. Front. 9:50-57. https://doi.org/10.1093/af/vfz039.

Bender, A. 1992. Meat and Meat Products in Human Nutrition in Developing Countries. Animal Production and Health Division and the Food Policy and Nutrition Division of FAO. Food and Nutrition paper No. 53. Rome, Italy. Accessed Dec., 1, 2019. http:// www.fao.org/3/T0562E/T0562E00.htm.

Blümmel, M., S. Anandan, and C. S. Prasad. 2009. Potential and limitations of by-product based feeding systems to mitigate greenhouse gases for improved livestock productivity. Pages 68-74 in 
Proc. 13th Biennial Conf. Anim. Nutr. Soc. India. National Institute of Animal Nutrition and Physiology, Bangalore, India.

Caro, D., E. Kebreab, and F. M. Mitloehner. 2016. Mitigation of enteric methane emissions from global livestock systems through nutrition strategies. Clim. Change 137:467-480.

Delgado, C., M. Rosegrant, H. Steinfeld, S. Ehui, and C. Courbois. 1999. Livestock to 2020: The Next Food Revolution. Food, Agriculture and Environment Discussion Paper 28. International Food Policy Research Institute, Washington, DC.

DeRamus, H. A., T. C. Clement, D. D. Giampola, and P. C. Dickison. 2003. Methane emissions of beef cattle on forages: Efficiency of grazing management systems. J. Environ. Qual. 32:269-277. https: //doi.org/10.2134/jeq2003.2690.

Dizyee, K., D. Baker, and A. Omore. 2019. Upgrading the smallholder dairy value chain: A system dynamics ex-ante impact assessment in Tanzania's Kilosa district. J. Dairy Res. 86:440-449. https://doi .org/10.1017/S0022029919000840.

Ducrocq, V., D. Laloe, M. Swaminathan, X. Rognon, M. Tixier-Boichard, and T. Zerjal. 2018. Genomics for ruminants in developing countries: From principles to practice. Front. Genet. 9:251. https:/ /doi.org/10.3389/fgene.2018.00251.

European Federation of Chemical Engineering. 2018. Accessed Dec. 19 2019. https://www.journals.elsevier.com/sustainable-production -and-consumption.

FAO. 2011a. World Livestock 2011-Livestock in food security. Food and Agriculture Organization of the United Nations. Rome, Italy.

FAO. 2011b. Successes and failures with animal nutrition practices and technologies in developing countries. Proceedings of the FAO Electronic Conference, Rome, Italy. FAO Animal Production and Health Proceedings. No. 11. H. P. S. Makkar, ed. Food and Agriculture Organization of the United Nations, Rome, Italy.

FAO. 2012. Balanced feeding for improving livestock productivity - Increase in milk production and nutrient use efficiency and decrease in methane emission. FAO Animal Production and Health Paper No. 173. M. R. Garg, ed. Food and Agriculture Organization of the United Nations, Rome, Italy.

FAO. 2018. FAOSTAT Database. Accessed Aug. 25, 2019. http://www fao.org/faostat/en/\#data.

FAO. 2020. Livestock and the environment. Accessed Oct. 17, 2019. http://www.fao.org/livestock-environment/en/.

FAO, GDP, and IFCN. 2018. Dairy Development's Impact on Poverty Reduction. Food and Agriculture Organization of the United Nations, Global Dairy Platform, and IFCN Dairy Research Network. Chicago, IL. Accessed Dec., 1, 2019. http://www.fao.org/3/ CA0289EN/ca0289en.pdf.

FAO-IDF. 2011. Guide to good dairy farming practice. Animal Production and Health Guidelines. No. 8. Food and Agriculture Organization of the United Nations, Rome, Italy; International Dairy Federation, Brussels, Belgium.

Fulgoni, V. L. 3rd, D. R. Keast, N. Auestad, and E. E. Quann. 2011. Nutrients from dairy foods are difficult to replace in diets of Americans: Food pattern modeling and an analyses of the National Health and Nutrition Examination Survey 2003-2006. Nutr. Res. 31:759-765. https://doi.org/10.1016/j.nutres.2011.09.017.

Garnett, T., M. C. Appleby, A. Balmford, I. J. Bateman, T. G. Benton, P. Bloomer, B. Burlingame, M. Dawkins, L. Dolan, D. Fraser, M. Herrero, I. Hoffmann, P. Smith, P. K. Thornton, C. Toulmin, S. J. Vermeulen, and H. C. J. Godfray. 2013. Sustainable intensification in agriculture: Premises and policies. Science 341:33-34. https: //doi.org/10.1126/science.1234485.

Gerber, P., T. Vellinga, K. Dietze, A. Falcucci, G. Gianni, J. Mounsey, L. Maiorano, C. Opio, D. Sironi, O. Thieme, and V. Weiler. 2010. Greenhouse gas emissions from the dairy sector-A life cycle assessment. Animal Production and Health Division. Food and Agriculture Organization of the United Nations, Rome, Italy.

Gerber, P. J., H. Steinfeld, B. Henderson, A. Mottet, C. Opio, J. Dijkman, A. Falcucci, and G. Tempio. 2013. Tackling climate change through livestock - A global assessment of emissions and mitigation opportunities. Food and Agriculture Organization of the United Nations, Rome, Italy.
Goswami, S. N., A. Chaturvedi, S. Chatterji, N. G. Patil, T. K. Sen, T. N. Hajare, and R. S. Gawande. 2013. Least cost diet plan of cows for small dairy farmers of Central India. Afr. J. Agric. Res. 8:5989-5995. https://doi.org/10.5897/AJAR11.1872.

Hagemann, M., A. Ndambi, T. Hemme, and U. Latacz-Lohmann. 2012. Contribution of milk production to global greenhouse gas emissions-An estimation based on typical farms. Environ. Sci. Pollut. Res. Int. 19:390-402. https://doi.org/10.1007/s11356-011 -0571-8.

Headey, D., K. Hirvonen, and J. Hoddinott. 2018. Animal sourced foods and child stunting. Am. J. Agric. Econ. 100:1302-1319. https://doi.org/10.1093/ajae/aay053.

Herrero, M., D. Grace, J. Njuki, N. Johnson, D. Enahoro, S. Silvestri, and M. C. Rufino. 2013. The roles of livestock in developing countries: The good, the bad and the knowledge gaps. Animal 7(s1):3-18. https://doi.org/10.1017/S1751731112001954.

High Level Panel of Experts (HLPE). 2017. Nutrition and food systems. A report by the High Level Panel of Experts on Food Security and Nutrition of the Committee on World Food Security, Rome, Italy. Accessed Sep. 1, 2019. http://www.fao.org/3/a-i7846e.pdf.

Hoddinott, J., D. Headey, and M. Dereje. 2015. Cows, missing milk markets, and nutrition in rural Ethiopia. J. Dev. Stud. 51:958-975. https://doi.org/10.1080/00220388.2015.1018903.

IAEA. 2007. Improving the reproductive management of dairy cattle subjected to artificial insemination. IAEA-TECDOC-1533. Animal Production and Health Section, Joint FAO/IAEA Division, International Atomic Energy Agency, Vienna, Austria.

Innovation Center for U.S. Dairy. 2014. Considerations and Resources on Feed and Animal Management. J. M. Tricarico, ed. Rosemont, IL. Accessed Dec. 19, 2019. https://www.usdairy.com/ /media/ usd/public/considerationsresourcesonfeedanimalmgt.pdf.

International Panel for Climate Change (IPCC). 2006. Guidelines for national greenhouse gas inventories, prepared by the national greenhouse gas inventories programme. H. S. Eggleston, L. Buendia, K. Miwa, T. Ngara, and K. Tanabe, ed. Institute for Global Environmental Strategies (IGES), Kanagawa, Japan.

Kavoi, M. M., D. L. Hoag, and J. Pritchett. 2010. Measurement of economic efficiency for smallholder dairy cattle in the marginal zones of Kenya. J. Dev. Agric. Econ. 2:122-137.

Keast, D. R., V. L. Fulgoni, T. A. Nicklas, and C. E. O'Neil. 2013. Food sources of energy and nutrients among children in the United States: National Health and Nutrition Examination Survey. Nutrients 5:283-301. https://doi.org/10.3390/nu5010283.

Kiplagat, S. K., M. K. Limo, and I. S. Kosgey. 2012. Genetic improvement of livestock for milk production. Pages 77-96 in Milk Production-Advanced Genetic Traits, Cellular Mechanism, Animal Management and Health. N. Chaiyabutr, ed. Intech Publishers, Rijeka, Croatia. https://doi.org/10.5772/50761.

Losinger, W. C., and A. J. Heinrichs. 1996. Dairy operation management practices and herd milk production. J. Dairy Sci. 79:506-514. https://doi.org/10.3168/jds.S0022-0302(96)76393-2.

Marshall, K., J. P. Gibson, O. Mwai, J. M. Mwacharo, A. Haile, T. Getachew, R. Mrode, and S. J. Kemp. 2019. Livestock genomics for developing countries-African examples in practice. Front. Genet. 10:297. https://doi.org/10.3389/fgene.2019.00297.

Martínez-García, C. G., S. J. Ugoretz, C. M. Arriaga-Jordán, and M. A. Wattiaux. 2015. Farm, household, and farmer characteristics associated with changes in management practices and technology adoption among dairy smallholders. Trop. Anim. Health Prod. 47:311-316. https://doi.org/10.1007/s11250-014-0720-4.

Mrode, R., J. Ojango, and O. Mwai. 2018. Developing innovative digital technology and genomic approaches to livestock genetic improvement in developing countries. J. Anim. Sci. 96(Suppl_3):507. https://doi.org/10.1093/jas/sky404.1109.

National Research Council. 2001. Nutrient Requirements of Dairy Cattle. 7th rev. ed. Natl. Acad. Press, Washington, DC.

Paul, S. S., A. B. Mandal, G. P. Mandal, A. Kannan, and N. N. Pathak. 2004. Deriving nutrient requirements of lactating Indian cattle under tropical condition using performance and intake data emanated from feeding trials conducted in different research insti- 
tutes. Asian-Australas. J. Anim. Sci. 17:769-776. https://doi.org/ 10.5713/ajas.2004.769.

Pressman, E., J. Schaefer, and E. Kebreab. 2018. Mitigation of enteric methane emissions from dairy cattle in East Africa through urea treatment of crop residue feeds. American Geophysical Union Fall 2018 Meeting Abstract. https://agu.confex.com/agu/fm18/ meetingapp.cgi/Paper/412733.

Salah, N., D. Sauvant, and H. Archimède. 2014. Nutritional requirements of sheep, goats and cattle in warm climates: A meta-analysis. Animal 8:1439-1447. https://doi.org/10.1017/S1751731114001153.

Tarawali, S., M. Herrero, K. Descheemaeker, E. Grings, and M. Blümmel. 2011. Pathways for sustainable development of mixed crop livestock systems: Taking a livestock and pro-poor approach. Livest. Sci. 139:11-21. https://doi.org/10.1016/j.livsci.2011.03.003.

UN DESA (UN Department of Economic and Social Affairs). 2018. The Sustainable Development Goals Report 2018. United Nations, New York, NY. https://doi.org/10.18356/7d014b41-en.

Val-Arreola, D., E. Kebreab, J. Dijkstra, and J. France. 2004. Study of the lactation curve in dairy cattle on farms in Central Mexico. J. Dairy Sci. 87:3789-3799. https://doi.org/10.3168/jds.S0022 -0302(04)73518-3.
Wattiaux, M. A. 2017. Dairy sector across the world: National trends and opportunities for sustainable growth. Pages 3-18 in Large Dairy Herd Management. 3rd ed. D. K. Beede, ed. American Dairy Association, Champaign, IL. https://doi.org/10.3168/ldhm.0101.

Weimar, M. R., and D. P. Blayney. 1994. Landmarks in the U.S. Dairy Industry. Agriculture Information Bulletin No. 694, Commodity Economics Division. Economic Research Service, USDA, Washington, DC.

World Bank. 2019. The World Bank and Nutrition. Accessed Dec. 19, 2019. https://www.worldbank.org/en/topic/nutrition/overview.

World Health Organization (WHO). 2018. Malnutrition. Fact Sheets Website. Accessed Dec. 19, 2019. https://www.who.int/news -room/fact-sheets/detail/malnutrition.

\section{ORCIDS}

J. M. Tricarico ® https://orcid.org/0000-0002-2101-1564

E. Kebreab () https://orcid.org/0000-0002-0833-1352

M. A. Wattiaux @ https://orcid.org/0000-0001-8713-1641 